\title{
Utilizing Cerlis Model in Improving Creative Writing Skills
}

\author{
Faridah Nazir, Zanariah Jano, Norliza Omar, Norzai Shahida Kamarudin
}

\begin{abstract}
The objectives of this paper were to identify the effectiveness of Cerlis Model in assisting teachers to improve students' creative writing skills such as descriptive and imaginative essays and to analyze whether the model can improve students' ways in expressing and organizing ideas in composing essays accurately. Samples consisted of 5 students from a primary school in Seremban, Negeri Sembilan. This study was conducted using a narrative qualitative approach through observation, questionnaire survey and document analysis and the results were reported using relevant tables, photos and visual graphics. The study focused among students that lack of ideas in producing creative essays such as descriptive and imaginative types. The results yielded that the Cerlis Model was able to create fun in learning and generate high confidence level in producing ideas for essay writing. Indeed, Cerlis Model is able to increase students' interests in writing essays and their comprehension level. This study also shows that games are generating students' ideas for composing descriptive and imaginative essays.
\end{abstract}

Keywords: Cerlis Model, creative writing, writing skills.

\section{INTRODUCTION}

In general, writing an essay refers to the act of using a pen, pencil or any writing tool to write or type any idea or statement. However, this definition is too general and mechanical in nature. Writing skills are vital in schools as students need them to show their adequate comprehension of each subject taught. Hence, students need guidance in essay writing skills so that they are able to apply them across the curriculum in order to produce more creative ideas. After identifying problems in writing, particularly in expressing and organizing ideas among students, Cerlis Model has been developed.

The objectives of this paper were to identify the effectiveness of Cerlis Model in assisting teachers to improve students' creative writing skills such as descriptive and imaginative essays and to analyze whether the model could improve students' ways in expressing and organizing ideas accurately for essay writing.

\section{LITERATURE REVIEW}

Previous studies have focused on the benefits of using teaching aids either in the forms of model or technology. In [3] asserted that although students have the limited capability and little knowledge, they are able to reconstruct ideas in the

Revised Version Manuscript Received on September 16, 2019.

Faridah Nazir, Kulliyyah of Language and Management, International Islamic University Malaysia, Pagoh, Johor, Malaysia.

Zanariah Jano, Centre of Language and Human Development, Technical University Malaysia, Melaka, Malaysia.

Norliza Omar, Kulliyyah of Language and Management, International Islamic University Malaysia, Pagoh, Johor, Malaysia.

Norzai Shahida Kamarudin, Jugra Primary School, Banting, Selangor, Malaysia. pursuit of exploring new things. In [4] noted that material-based learning is seen as an effective alternative in the teaching and learning process as it is able to create student-centered learning.

In this regard, according to [6], the development of technology in the creation of teaching and learning equipment has a real impact in delivering the knowledge and skills of teachers as well as in accelerating the learning process among students and saving teachers' time. In [8] agree that by utilizing attractive teaching aids, the quality of teaching and students' performance can be improved. According to him, young students are making logical reasoning but are still bound to concrete and interesting objects to understand a new phenomenon.

\section{CERLIS MODEL}

Cerlis Model or story writing is based on a housing area model or an actual residential area as shown in Fig. 1. This model is equipped with human paper figures, aiming to generate students' ideas in storytelling activities and eventually organize the ideas in essay writing.

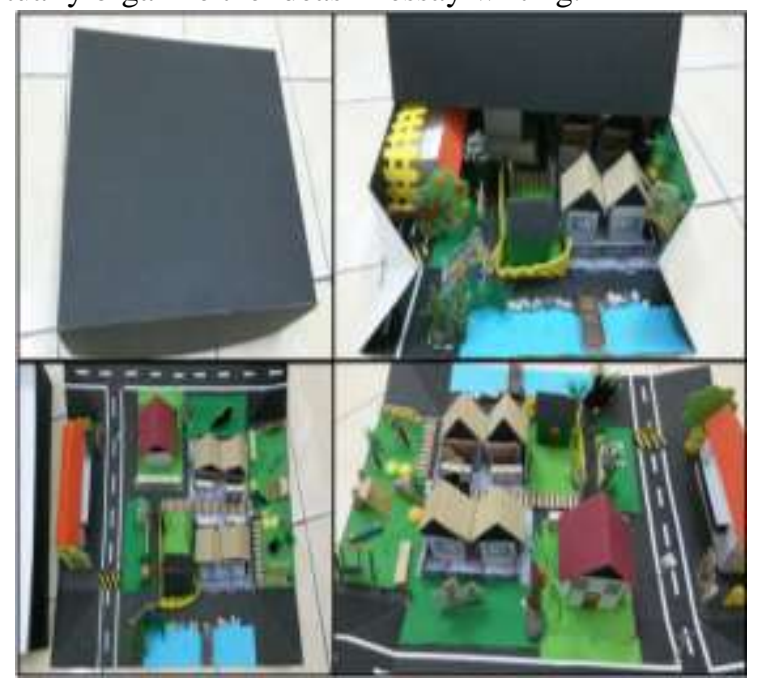

Fig. 1: Cerlis Model

The study focuses on essay writing problems and creative idea generation in producing essays. Problems in writing among students are identified during an initial observation in the Malay Language class. Students are facing difficulties in structuring sentences in relation to picture stimulus. Besides, students tend to have difficulties in expressing ideas for guided creative essay writing such as descriptive and imaginative essays. 


\section{METHODOLOGY \& RESULTS}

\section{A. Samples}

A total of five students from the primary National School at the suburb of Seremban, Negeri Sembilan were selected for this study. The participants of this study consisted of three Malay boys and two Malay girls. The students who have difficulties in constructing correct sentences were selected.

\section{B. Theoretical framework}

A model of action research [5] as shown in Fig. 2 was utilized for this model is user-friendly. In [5] comprises four phases namely planning, acting, observing and reflection.

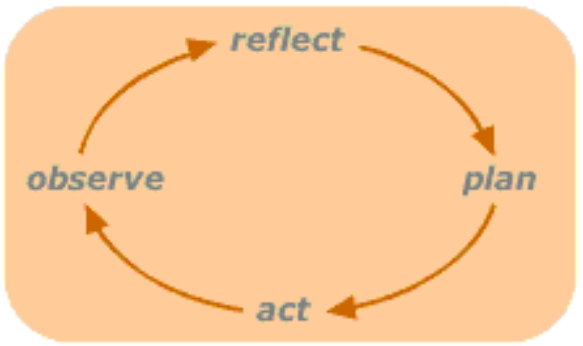

Fig. 2: Model of action research [5]

In addition, in [5] also proposed a cycle concept in action research as shown in Fig. 3.

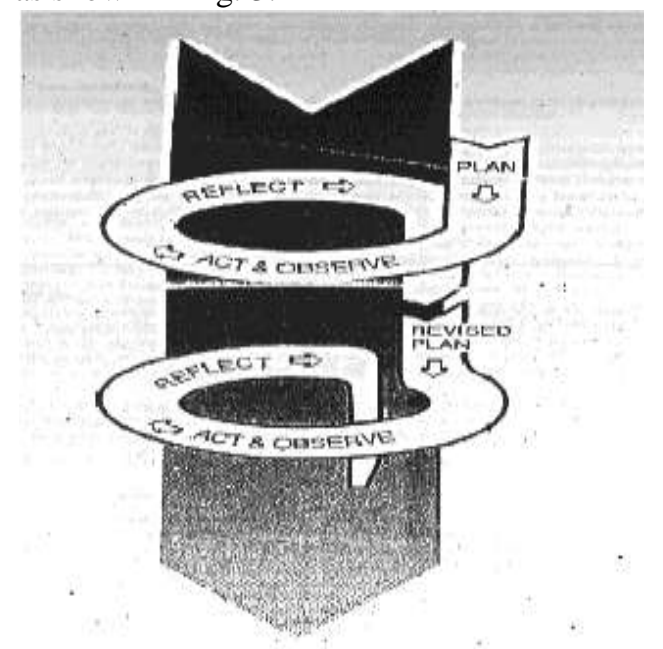

Fig. 3: A cycle concept in action research

\section{Procedure}

Based on Fig. 3, the action research process started with the teacher reflecting on the issue of teaching and learning to be addressed. Then, the teacher provided a suitable plan to deal with the problems he faced. Then the teacher implemented the plan and in the process of implementation the teacher was to observe the progress of the action. The whole implementation was described as the First Ring (cycle 1) and if the problem was not resolved, then the teacher could start the process again up to the Second Ring (cycle 2) until the problem is solved. In the Second Ring, the teacher must reflect and adapt to his or her action plan. This study utilized a cycle as shown in Fig. 2.

In this regard, this study is also an action research conducted on two loops, the first and second loop. During the first loop, researchers used the Model of [5]. This study focused on students who cannot express ideas in creative writing in the form of guided imaginative and descriptive essays. At this stage, supplementary material construction was designed to generate more creative ideas in the guided writing.

The first and second phases were executed and a Daily Teaching Plan was produced. The 1-hour teaching session was conducted in the classroom, focusing on teaching objectives where students could write imaginative and descriptive creative essays using the Cerlis Model. In this regard, the second objective was that students were able to submit and put ideas into writing correctly according to the Cerlis Model. The teaching and learning of creative writing in the form of imaginative and descriptive essays using Cerlis Model were observed and recorded. Besides recording and observation, survey via questionnaire and document analysis were also conducted.

Next, the reflection process was implemented on the implementation of action to identify whether the objectives of the study were achieved or not. This phase also enabled researchers to identify the advantages and disadvantages of the teaching and learning process. In addition, researchers can also reassess the teaching process after using the Cerlis Model. Through this first loop, it was found that the Cerlis Model should be improved as it is not suitable for students to carry out storytelling activities as they face difficulties in comprehending the story itself prior to the actual storytelling session.

Subsequently, the second loop was carried out with the improved Cerlis Model. The researchers have added models such as football fields, rivers, bridges, schools and social activities in the Cerlis Model. After this improvement, it was found that students' minds have been challenged and stimulated to produce creative ideas.

\section{DAILY TEACHING PLAN OF THE CERLIS MODEL}

Daily Teaching Plan is prepared at the level of action planning and applied during the activity implementation and observation session. The preparation for the Daily Teaching Plan through Cerlis Model is included in the teaching Aid in the teaching and learning of creative writing skills in terms of descriptive and imaginative essays.

Daily teaching plan

Date: 24 May 2019

Year: 3 Perdana

Number of students: 30

Time: $11.00-12.00$

Theme: Unity

Title: Healthy well-being through good values

Skills: Writing

Standard Content: 3.7 To produce creative writing in various genres accurately.

Standard Learning Outcomes: 3.7.2 To produce creative writing in terms of guided descriptive and imaginative essays.

Objectives: At the end of the teaching and learning session, students will be able to: 
1. Produce ideas using Cerlis Model and organize them in writing essays.

2. Produce descriptive writing (explanation based) in a $\log$ book.

\section{Content of curriculum}

Knowledge: Life skills

Values: Collaboration, politeness, tolerance

Sociocultural Rules: Language level, politeness in language

EMK: Creativity and Innovation: Idea generation and new idea production.

\begin{tabular}{|c|c|c|c|}
\hline Steps / Time & Content & Teaching and Learning Activities & Remarks \\
\hline $\begin{array}{l}\text { Induction Set } \\
5 \text { minutes }\end{array}$ & $\begin{array}{l}\text { Question } \\
\text { Who is your neighbour? } \\
\text { What are good values } \\
\text { displayed in the picture? } \\
\text { What is the importance of } \\
\text { neighbour to you? } \\
\text { Do you always help your } \\
\text { neighbour? }\end{array}$ & $\begin{array}{l}\text { 1.Students are shown the flash cards } \\
\text { about good values in the neighborhood } \\
\text { 2. Students and teacher have a } \\
\text { question-answer session on the flash } \\
\text { cards by stating their values . } \\
\text { 3. Teachers associate the discussion } \\
\text { with the theme and topic of the lesson. }\end{array}$ & $\begin{array}{l}\text { TA } \\
\text { Flash Cards } \\
\text { Strategy } \\
\text { Association } \\
\text { Idea generation } \\
\text { Analysis } \\
\text { Value } \\
\text { Collaboration } \\
\text { Politeness } \\
\text { Tolerance } \\
\text { Empathy }\end{array}$ \\
\hline $\begin{array}{c}\text { Step 1 } \\
15 \text { minutes }\end{array}$ & Cerlis Model & $\begin{array}{l}\text { Teachers demonstrates neighborhood } \\
\text { housing concept model to students. } \\
\text { Students are asked to give a view on the } \\
\text { friendly neighborhood concept by } \\
\text { referring to the model of the housing } \\
\text { park. } \\
\text { Students need to identify the } \\
\text { neighborhood-friendly values found in } \\
\text { the housing park model. }\end{array}$ & $\begin{array}{l}\text { Value } \\
\text { Collaboration, } \\
\text { Appreciation, } \\
\text { Acknowledgement }\end{array}$ \\
\hline
\end{tabular}

Teaching Strategy: Added value skills

i) Critical Thinking Skills: Producing sequence.

ii) Creative Thinking Skills: Generating ideas.

iii) Multi Intelligence: Verbal, linguistics, music

iv) Learning How to Learn: Writing.

Existing Knowledge: Students already know the format for guided essays based on pictures.

Language System: Syntax: Guided essays

Teaching Resources: i) Cerlis Model

ii) Watching video 


\begin{tabular}{|c|c|c|c|}
\hline $\begin{array}{c}\text { Step } 2 \\
15 \text { minutes }\end{array}$ & $\begin{array}{l}\text { Students generate ideas and } \\
\text { produce as many ideas as } \\
\text { possible with the movements } \\
\text { they make using the paper } \\
\text { statues provided. } \\
\text { Example: My name is Akif, } \\
\text { this is my housing area. I live } \\
\text { in Taman Orkid, Seremban } \\
\text { Negeri Sembilan. I have } \\
\text { four very kind neighbors. } \\
\text { They always lend a helping } \\
\text { hand when my family is in } \\
\text { trouble. Neighbours are those } \\
\text { who live near our home. } \\
\text { During weekend, we will } \\
\text { gather in the park to clean the } \\
\text { area (telling stories as } \\
\text { students move the paper } \\
\text { statues). }\end{array}$ & $\begin{array}{l}\text { 1. Each student is to tell his/her journey } \\
\text { in the Cerlis Model to the class. } \\
\text { 2. Each student is given paper statue } \\
\text { that reflect him/her. } \\
\text { 3. Student tell a story by moving the } \\
\text { paper statues against the Cerlis Model } \\
\text { and tell a story according to the } \\
\text { neighborhood concept through their } \\
\text { experience. } \\
\text { 4. Students are to recount their } \\
\text { experience when moving the paper } \\
\text { statue in front of the class. } \\
\text { 5. Teachers make a summary of student } \\
\text { findings. }\end{array}$ & \\
\hline $\begin{array}{c}\text { Step } 3 \\
20 \text { minutes }\end{array}$ & $\begin{array}{l}\text { Descriptive Essay writing - } \\
\text { Write in a book. }\end{array}$ & $\begin{array}{l}\text { Assessment } \\
\text { Students are asked to write an essay } \\
\text { from the ideas of using the Cerlis } \\
\text { Model. } \\
\text { Enrichment } \\
\text { Students complete the essays and } \\
\text { provide further descriptions based on } \\
\text { the Cerlis Model. } \\
\text { Recovery } \\
\text { Students are guided to generate ideas } \\
\text { with the help of teachers using the } \\
\text { Cerlis Model. }\end{array}$ & $\begin{array}{l}\text { TA } \\
\text { Work log } \\
\text { Strategy } \\
\text { Idea generation } \\
\text { Writing } \\
\\
\text { Value } \\
\text { Hard work } \\
\text { Politeness } \\
\text { Collaboration }\end{array}$ \\
\hline $\begin{array}{l}\text { Closure } \\
5 \text { minutes }\end{array}$ & $\begin{array}{l}\text { Cognitive Closure } \\
\text { Teachers summarize the } \\
\text { Teaching and Learning } \\
\text { session. }\end{array}$ & $\begin{array}{l}\text { 1. Students are to review the lesson } \\
\text { learned today. } \\
\text { 2. Teacher and students have a } \\
\text { question-answer session and teacher } \\
\text { summarizes the teaching and learning } \\
\text { outputs of the day. }\end{array}$ & $\begin{array}{l}\text { TA } \\
\text { Video Clip } \\
\text { Strategy } \\
\text { Verbal } \\
\text { Linguistics } \\
\text { Music } \\
\text { Value } \\
\text { Collaboration } \\
\text { Summary } \\
\end{array}$ \\
\hline
\end{tabular}

\section{RESULTS AND ANALYSIS}

Overall, based on the findings of the three instruments, the objectives of this study have been achieved. Based on the first objective, the quality of teacher teaching in teaching students to write creative ideas in the form of imaginative and descriptive essay using the Cerlis Model increases. Students are very keen to talk to the Cerlis Model and have been able to handle it well on their own. The teacher does not have to give a lot of information as students are stimulated through the Cerlis Model and aided by their imagination.

Based on the satisfaction feedback of the Cerlis Model using the questionnaire, a total of five respondents (100\%) stated, "I enjoyed using the Cerlis Model." In addition, a total of five students also (100\%) stated "I am passionate about taking the Malay language classes."
The quality of teaching also improved as class control improved after the use of Cerlis Model. The five students responded positively and they were not complacent with anything other than the teacher's teaching. This fact is proven again during an induction set when a student responded positively when asked by the teacher. In addition, the findings also showed that the use of this model saved time for teachers. The teacher does not need to explain how to present ideas in writing. Students will spontaneously submit their ideas based on the Cerlis Model, where teachers only guide occasionally. 
Furthermore, the findings of the study for objective 2, showed that the Cerlis Model has helped the students to present sound ideas in guided writing. The Cerlis Model has been able to stimulate the students' mind as the material used was 3D-like, resembling a real estate park. This model is also easily understood by students as they can imagine through what they have seen directly. This is evidenced in 39:53 minutes, when one of the study participants woke up and looked back at the Cerlis Model to get even more ideas. The participants enjoyed using the Cerlis Model as they succeeded in producing guided writing with divergent ideas. Based on the questionnaire it was found that $100 \%$ of students enjoyed using the Cerlis Model.

The students' interest in studying also increased from $80 \%$ to $100 \%$ throughout the teaching and learning sessions. This finding can be clearly demonstrated when the five participants can relate their experience when moving the paper statues on the Cerlis Model. Subsequently, the five participants could write the essay from the idea of using the Cerlis Model and complete the essay with a description based on the Cerlis Model. At the end of the teaching and learning sessions, the participants were able to restate what they learned and enjoyed learning based on the Cerlis Model. All participants were also highly motivated when their work showed improvement.

\section{DISCUSSION}

In this study, the use of the Cerlis Model particularly to write imaginative and descriptive essays has facilitated the teacher's work as it has been fully utilized by students. Teachers only become observers and facilitators when problems emerge. The use of attractive material such as the Cerlis Model is different from pictorial and printed materials to stimulate the students' minds. Picture-only materials cause students to not understand what teachers are really saying. Through this study, teachers' motivation has also increased. This is in line with the findings of [1], [2] that show teachers are positive and have high confidence in utilizing fun learning and teaching.

Additionally, the use of Cerlis Model is similar to language games which has also shown improved class control. This is in line with the study of [7] which stated that one of the learning media that facilitates and conforms to psychological developments and language development is the teaching of language game. It can be concluded that, the Cerlis Model has managed to create a fun and controlled learning culture as students are always curious about what they are learning.

\section{CONCLUSION}

The use of the Cerlis Model rhymes with the interest of students in playing while learning because the students enjoy using it. Teachers only act as facilitators, where students can use the Cerlis Model to produce interesting, descriptive essays. Indeed, the Cerlis Model triggers students' ideas without any boundaries. This is because, all students are creative and only creative and fun teaching materials such as the Cerlis Model are capable of generating creative qualities amongst students.

Interestingly, Cerlis Model has facilitated teachers and students to produce interesting and descriptive essays. If before, students are faced with a variety of problems, especially to present interesting ideas but the use of the Cerlis Model has changed this scenario. Teachers' role as facilitators are also enhanced which lead to independent learning among students. The use of the Cerlis Model is in line with the teaching strategies that have been used, namely material-centered strategies. The process of teaching and learning will be more effective if all students focus on teaching materials and at the same time facilitate teachers' tasks.

Few suggestions are worth noted for this study. Firstly, the number of participants must be added so that the findings of this study will be more robust. Secondly, several different Cerlis Model can be built on various themes for example, the theme of agriculture and animal husbandry. The next suggestion is to diversify other skills such as text-based reading skills in the model, as the model is now only relevant for speaking and writing skills. In addition, the Cerlis Model will also be modified to be used in other subjects as well. For example, for historical subjects, this model can be modified subject to arising needs.

\section{REFERENCES}

1. A. R. Jamian, "Permasalahan kemahiran membaca dan menulis Bahasa Melayu murid-murid sekolah rendah di luar bandar," Jurnal Pendidikan Bahasa Melayu, 1(1), 2016, pp. 1-12.

2. A. R. Jamian and and H. Ismail, "Pelaksanaan pembelajaran menyeronokkan dalam pengajaran dan pembelajaran Bahasa Melayu." Jurnal Pendidikan Bahasa Melayu, 3(2), 2016, pp. 49-63.

3. A. Hamzah, S. N. S. Idrus, and Z. M. Ashari, Peranan Aktiviti Bermain dalam Merangsang Dimensi Perkembangan Kognitif Kanak-Kanak Prasekolah: Kajian Kes. Pulau Pinang: Universiti Sains Malaysia, 2009.

4. I. Kailani and L. H. Muhammed, "Pembangunan bahan E-Pembelajaran berasaskan Moodle bagi tajuk Ratios, Rates and Proportions 11 Tingkatan Tiga," Journal of Educational Science and Mathematics, 1, 2011, pp. 35-43.

5. S. Kemmis and R. McTaggart, The Action Research Planner. Victoria: Deakin University Press, 1988.

6. O. Ashaari, Pengajaran Kreatif untuk Pembelajaran Aktif Kuala Lumpur: Dewan Bahasa dan Pustaka, 1999.

7. S. Sugirasih, Permainan bahasa dalam pembelajaran bahasa Indonesia di sekolah dasar. Master thesis, Indonesia: Yogyakarta State University, 2010.

8. W. K. Wah, K. Mohamad, M. Alias, R. A. Rashid, and A. Ahmad, Perkembangan Kanak-Kanak. Kuala Lumpur: Oxford Fajar Sdn Bhd, 2013. 